\title{
VERTICAL DISTRIBUTION OF NON METHANE HYDROCARBONS IN THE REMOTE MARINE BOUNDARY LAYER
}

\author{
B. Bonsang, ${ }^{1}$ D. Martin, ${ }^{2}$ G. Lambert, ${ }^{1}$ M. Kanakidou, ${ }^{1,3}$ \\ J.C. Le Roulley, ${ }^{1}$ and G. Sennequier ${ }^{2}$
}

\begin{abstract}
The marine production and vertical atmospheric distribution of light nonmethane hydrocarbons (NMHC) from $\mathrm{C}_{2}$ to $\mathrm{C}_{6}$ in the marine boundary layer was studied at the Hao atoll, in the intertropical South Pacific. NMHC vertical profiles were performed up to $1600 \mathrm{~m}$ altitude by using balloon and remote controlled aircraft-borne devices simultaneously with surface air and seawater samplings. Seawater was found to be supersaturated in NMHC. Despite the concentration variations of the seawater its relative composition is well reproducible, within a factor of 2 . The average NMHC atmospheric composition at sea level is similar to that of seawater. However, the results obtained display a very large short time variability of the NMHC atmospheric concentrations, which seems to result mainly from variations in the marine emission rates and/or advective processes of transport. It was initially expected that the proportions of short-lived species should rapidly decrease in altitude, because of their chemical decay, mainly by oxidation by $\mathrm{OH}$ radicals. However, it appeared that the proportions of the different NMHC measured remained relatively constant up to the maximum altitude sampled during the campaign, i.e., about $1600 \mathrm{~m}$. This suggests that transport processes in the atmosphere were always very rapid, relative to the chemical processes, even for short-lived NMHC. However, for reactive species, simple calculations based on the hypothesis of a steady state in thin atmospheric layers show that the photochemistry involved is consistent with usual $\mathrm{OH}$ concentrations varying from $1.6 \times 10^{7} \mathrm{rad} \mathrm{cm}^{-3}$ at noon to 4 $x 10^{4} \mathrm{rad} \mathrm{cm}^{-3}$ at sunset.
\end{abstract}

\section{Introduction}

Non methane hydrocarbons (NMHC) are produced by multiple sources and released into the atmosphere where they are destroyed by homogeneous chemical reactions involving $\mathrm{OH}$ radicals and, to a lesser extent, $\mathrm{O}_{3}$ oxidation. Despite their low mixing ratios in the remote troposphere of a few hundred parts per trillion, i.e. 3 or 4 orders of magnitude lower than methane, they can be of importance for the chemistry of the troposphere, and particularly for the ozone and odd hydrogen radicals budgets.

$\mathrm{C}_{2}-\mathrm{C}_{3}$ NMHC have been detected in the surface seawater in concentrations similar to that of methane [Swinnerton and Linnenbon, 1967; Lamontagne et al., 1973]. More recently, Bonsang et al. $[1988,1989]$ have found that a wider range of $\mathrm{NMHC}$ from $\mathrm{C}_{2}$ to $\mathrm{C}_{6}$ were surpersaturated in surface

1 Centre des Faibles Radioactivités, Laboratoire mixte CNRS/CEA domaine du CNRS, Gif-sur-Yvette, France.

2 Direction de la Météorologie Nationale, Etablissement d'Etudes et de Recherches Météorologiques,

Magny-les-Hameaux, France.

3 Now at Max Planck Institute for Chemistry, Mainz, Germany.

\section{Copyright 1991 by the American Geophysical Union.}

Paper number 90JD02539.

0148-0227/91/90JD-02539\$05.00 seawater by 2 or 3 orders of magnitude with respect to the atmosphere. Both long-lived and short-lived NMHC are produced by the ocean surface, but, whereas the long-lived species are assumed to mix in the whole troposphere [Aikin et al., 1987], short-lived species are expected to decrease rapidly versus altitude. However, the few vertical profiles obtained over the ocean [Ehhalt et al., 1985; Dickerson et al., 1987; Singh et al., 1988; Greenberg et al., 1990] have shown that the short-lived NMHC are actually transported in altitude, likely by fast vertical advections.

In order to investigate the importance of NMHC in the photochemistry of the marine atmosphere the vertical distribution of light hydrocarbons from $C_{2}$ to $C_{6}$ in the marine atmospheric boundary layer was studied in a remote oceanic site in the intertropical South Pacific. NMHC vertical profiles were performed up to $1600 \mathrm{~m}$ altitude by using balloon and remote controlled aircraft-borne devices simultaneously with surface air and seawater samplings.

\section{Experimental Procedure}

The measurements were performed in 1987 from May 31 to June 11 on the Hao atoll $\left(18^{\circ} 04^{\prime} \mathrm{S}, 140^{\circ} 58^{\prime} \mathrm{W}\right)$ in the Pacific Ocean (Figure 1). This site was selected for its isolation at the east of the Tuamotu Archipelago, far from the usual anthropogenic sources of pollution.

Owing to the general circulation of air masses at this latitude, the sampling site was located on the north part of the atoll at $5 \mathrm{~km}$ northwest the small village of Hao (Figure 1). However, a variability in the wind direction was observed during the experiment, therefore in order to avoid any contamination by human activities the samplings were conducted only when the sampling site was upwind the village. At the sampling place the width of the atoll between ocean and lagoon was about $100 \mathrm{~m}$, and the influence of the local scarce vegetation was negligible. In addition, three seawater samples were collected at 5 nautical miles northerly of the atoll, and one sample was collected in the lagoon.

Grab air samples were collected in 6 L-stainless steel electropolished canisters, manually opened at sea surface level or automatically opened in altitude. For this purpose, automated valves were fitted on the canisters. Samples were collected with meteorological balloon carrying a load of three canisters. Each sample was collected by opening the valve at a preselected altitude measured with a pressure sensor. Once the last sample collected, the load was automatically disconnected and dropped with a parachute in the lagoon where it was recovered. A tethered balloon was also used in order to take samples at low altitudes. Occasionally, the sampling cylinders were adapted on a remote piloted aircraft (SAM for "Sonde Aérologique Motorisée") used for micrometeorological measurements. NMHC atmospheric concentrations measured by using this device were comparable to those obtained by using the other sampling systems. Low acetylene concentrations indicate the absence of any pollution effect on the air samples collected by using the remotely controled aircrafts; moreover, as shown by Kanakidou et al. [1988], this acetylene was probably entirely released from the sea.

Seawater samples were outgassed with ultra pure helium, by an head space equilibration technique. Dissolved NMHC in seawater were then analyzed by gas chromatography with the same technique as for air samples [Bonsang et al., 1987]. 

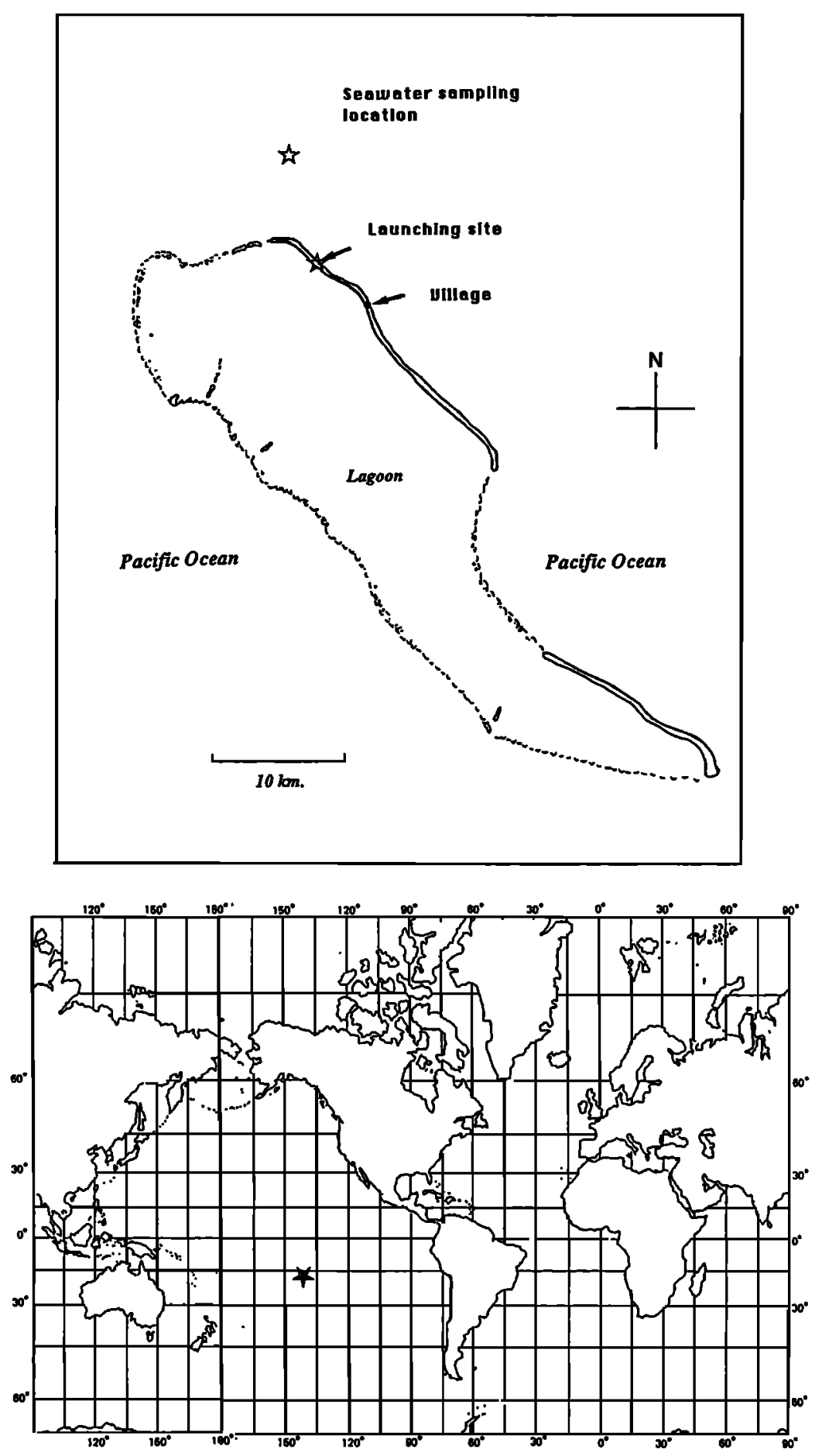

Fig.1. Map of atoll of Hao and location in the Pacific Ocean (18 $04^{\prime}$ 'S-140 $58^{\prime} \mathrm{W}$ ).

Sample analysis was performed in the laboratory within 2 months after the experiment. For this purpose a gas chromatograph equiped with a flame ionisation detector was used. 0.5 to $1 \mathrm{~L}$ of air sample was dried by a potassium carbonate trap and cryogenically enriched in a tenax trap cooled at $-120^{\circ} \mathrm{C}$. After this first enrichment step the sample was tranferred into the chromatographic column (porous layer open tubular column, $\mathrm{KCl} / \mathrm{Al}_{2} \mathrm{O}_{3}$ ) cooled at $-80^{\circ} \mathrm{C}$, and temperature programmed to $120^{\circ} \mathrm{C}$ according to a technique described elsewhere [Kanakidou et $11 . .19881$. Interferences with ozone during the enrichment step have not been checked, because they are unlikely owing to the trapping temperature $\left(-120^{\circ} \mathrm{C}\right)$. The accuracy of the analysis was estimated at 5 to $10 \%$, the minimum detectable linit was 5 pptv for most of the $\mathrm{C}_{2}-\mathrm{C}_{5} \mathrm{NMHC}$.

The meteorological data used to interpret the NMHC profiles have been provided by the French meteorological weather service as well as by the European Center of Medium Range Weather Forecast (ECMWF, Reading, United Kingdom). The data include daily radiosoundings of Rapa 
$\left(27^{\circ} 37^{\prime} \mathrm{S} ; 144^{\circ} 20^{\prime} \mathrm{W}\right)$, Tahiti-Faa $\left(17^{\circ} 33^{\prime} \mathrm{S} ; 149^{\circ} 37^{\prime} \mathrm{W}\right)$, and Hao ( $\left.18^{\circ} 04^{\prime} \mathrm{S} ; 140^{\circ} 58^{\prime} \mathrm{W}\right)$, performed for the world meteorological network. Infrared satellites images from the National Óceanic and Atmospheric Administration (NOAAGOES) have also been used when they were available. Furthermore, detailed pressure, temperature, and humidity profiles (PTU) up to about $1000 \mathrm{~m}$ height were measured over the atoll, by using the remote piloted aircraft [Martin, 1980]. These PTU profiles were obtained just when the NMHC airborne samplings were completed. Moreover, ten days backward trajectories have been computed for three ending levels $(925,850$, and $700 \mathrm{hPa})$ at Hao. Trajectories calculations were made by taking into account the synoptic vertical motions, particularly important in tropical regions, as described and discussed by Martin et al. [1987, 1990].

The period from May 31 to June 11, 1987, was characterized by successive perturbations associated with the proximity of the intertropical convergence zone (ITCZ). ITCZ was oscillating northem and southem of the sampling site leading to unusual precipitations and inducing variable wind in strength and direction. The wind velocity at $10 \mathrm{~m}$ altitude was generally of the order of $3-5 \mathrm{~m} / \mathrm{s}$ during the campaign and reached a maximum of $15 \mathrm{~m} / \mathrm{s}$ on June 7 .

\section{Results and Discussion}

Seven atmospheric NMHC vertical profiles were obtained in the marine boundary layer from May 31 to June 11, 1987: four profiles during daytime or at twilight up to an altitude of $1600 \mathrm{~m}$; three profiles at night at lower altitudes, up to $300 \mathrm{~m}$. Ten air samples were collected at sea level; three seawater samples were collected in the open ocean and one additional in the lagoon.

The NMHC concentrations in seawater, expressed in ppbv $\left(10^{-9} \mathrm{~cm}^{3}\right.$ gas $/ \mathrm{cm}^{3}$ of water at $\left.30^{\circ} \mathrm{C}\right)$ are reported in Table 1 . The atmospheric mixing ratios for the seven flights are reported in Table 2.

TABLE 1. Concentrations of Dissolved Hydrocarbons in Seawater and Ratios to Ethene

\begin{tabular}{|c|c|c|c|c|c|c|c|}
\hline \multicolumn{8}{|c|}{ Date } \\
\hline & \multicolumn{2}{|c|}{ June 4, 1987} & \multicolumn{2}{|c|}{ June 7, 1987} & \multicolumn{2}{|c|}{ June 11,1987} & June 5, 1987 \\
\hline \multirow{4}{*}{$\begin{array}{l}\text { Local Hour } \\
\text { Water } \\
\text { temperature } \\
\text { Air temperature } \\
\text { Wind speed }\end{array}$} & \multicolumn{2}{|l|}{1430} & \multicolumn{2}{|l|}{0925} & \multicolumn{2}{|l|}{0605} & 1410 \\
\hline & \multicolumn{2}{|c|}{$\begin{array}{l}28^{\circ} \mathrm{C} \\
27^{\circ} \mathrm{C} \\
9.5 \mathrm{~m} / \mathrm{s}\end{array}$} & \multicolumn{2}{|c|}{$\begin{array}{l}28^{\circ} \mathrm{C} \\
24^{\circ} \mathrm{C} \\
13.5 \mathrm{~m} / \mathrm{s}\end{array}$} & \multicolumn{2}{|c|}{$\begin{array}{l}28^{\circ} \mathrm{C} \\
26.3^{\circ} \mathrm{C} \\
5 \mathrm{~m} / \mathrm{s}\end{array}$} & $\begin{array}{l}30^{\circ} \mathrm{C} \\
27^{\circ} \mathrm{C} \\
7.5 \mathrm{~m} / \mathrm{s}\end{array}$ \\
\hline & \multicolumn{2}{|c|}{ Concentration } & \multicolumn{2}{|c|}{ Concentration } & \multicolumn{2}{|c|}{ Concentration } & \multirow{2}{*}{$\begin{array}{c}\text { Concentration* } \\
\text { ppbv }\end{array}$} \\
\hline & ppbv & Ratio & ppbv & Ratio & ppbv & Ratio & \\
\hline \multirow[t]{2}{*}{$\mathrm{C}_{2} \mathrm{H}_{2}$} & 0.52 & 0,190 & 9.32 & 0,159 & 2.20 & 0,058 & 2.20 \\
\hline & \multicolumn{6}{|c|}{ Alkanes } & \\
\hline $\mathrm{C}_{2} \mathrm{H}_{6}$ & 1.50 & 0,549 & 21.81 & 0,373 & 39.62 & 1,051 & 4.81 \\
\hline $\mathrm{C}_{3} \mathrm{H}_{8}$ & 1.39 & 0,509 & 13.55 & 0,232 & 17.94 & 0,476 & 3.06 \\
\hline $\mathrm{i} \mathrm{C}_{4} \mathrm{H}_{10}$ & 0.29 & 0,106 & 3.62 & 0,062 & 2.53 & 0,067 & 0.40 \\
\hline $\mathrm{n} \mathrm{C}_{4} \mathrm{H}_{10}$ & 0.65 & 0,238 & 7.44 & 0,127 & 9.60 & 0,255 & 1.10 \\
\hline $\mathrm{i}_{5} \mathrm{H}_{12}$ & 0.44 & 0,161 & 11.42 & 0,195 & 3.29 & 0,087 & 1.26 \\
\hline $\mathrm{n} \mathrm{C}_{5} \mathrm{H}_{12}$ & 0.71 & 0,260 & 11.68 & 0,200 & 4.33 & 0,115 & 1.19 \\
\hline \multirow[t]{2}{*}{$\mathrm{n} \mathrm{C}_{6} \mathrm{H}_{14}$} & 0.38 & 0,139 & 7.65 & 0,131 & 1.66 & 0,044 & 0.93 \\
\hline & \multicolumn{6}{|c|}{ Alkenes } & \\
\hline $\mathrm{C}_{2} \mathrm{H}_{4}$ & 2.73 & 1,000 & 58.44 & 1,000 & 37.69 & 1,000 & 230.4 \\
\hline $\mathrm{C}_{3} \mathrm{H}_{6}$ & 5.87 & 2,150 & 74.51 & 1,275 & 70.21 & 1,863 & 9.55 \\
\hline trans-2- $\mathrm{C}_{4} \mathrm{H}_{8}$ & 0.30 & 0,110 & 3.92 & 0,067 & 2.84 & 0,075 & 0.46 \\
\hline $1 \mathrm{C}_{4} \mathrm{H}_{8}$ & 1.78 & 0,652 & 22.19 & 0,380 & 28.06 & 0,744 & 1.85 \\
\hline $\mathrm{i} \mathrm{C}_{4} \mathrm{H}_{8}$ & 4.02 & 1,473 & 38.53 & 0,659 & 21.80 & 0,578 & 5.52 \\
\hline cis- $2-\mathrm{C}_{4} \mathrm{H}_{8}$ & 0.26 & 0,095 & 3.12 & 0,053 & 4.70 & 0,125 & 0.36 \\
\hline $1 \mathrm{C}_{5} \mathrm{H}_{10}$ & 1.33 & 0,487 & 13.01 & 0,223 & 10.65 & 0,283 & 1.06 \\
\hline $1 \mathrm{C}_{6} \mathrm{H}_{12}$ & 0.43 & 0,158 & 3.70 & 0,063 & 4.30 & 0,114 & 0.49 \\
\hline
\end{tabular}

Concentrations in parts per billion by volume (ppbv) $\left(10^{-9} \mathrm{~L}\right.$ of gas per liter of water at $28^{\circ} \mathrm{C}$ ) Ratios are to ethene.

* Lagoon sample 
TABLE 2. $\mathrm{CH}_{4}$ and NMHC Mixing Ratios Above the Hao Atoll

\begin{tabular}{|c|c|c|c|c|c|c|c|c|c|c|c|c|}
\hline & & & & & Flight & Numbe & & & & & & \\
\hline & 1 & $\mathbf{1}$ & 1 & 1 & - & 2 & 2 & 3 & 3 & - & - & 4 \\
\hline Date & May 31 & May 31 & May 31 & May 31 & May 31 & June 2 & June 2 & June 3 & June 4 & June 5 & June 7 & Junes \\
\hline Local hour & 1450 & 1430 & 1200 & 1200 & 2100 & 2250 & 2230 & 2240 & 0010 & 1400 & 1030 & 1705 \\
\hline Altitude, m & 0 & 100 & 400 & 1000 & 0 & 0 & 100 & 300 & 0 & 0 & 0 & 0 \\
\hline Wind direction & 340 & & & & & 360 & & & 320 & 240 & 80 & 80 \\
\hline Wind speed, $\mathrm{m} / \mathrm{s}$ & 5 & & & & & 8.5 & & & 5 & 7.5 & 13.5 & 11 \\
\hline $\mathrm{UV}, \mathrm{mW} / \mathrm{cm}^{2}$ & 3.6 & 3.6 & 4.2 & 4.2 & $\mathbf{0}$ & 0 & $\mathbf{0}$ & 0 & 0 & & & 0.1 \\
\hline Sampling mean & MAN & T.B. & B. & B. & MAN & MAN & T.B. & T.B. & MAN & MAN & T.B. & B. \\
\hline $\mathrm{CH}_{4}, \mathrm{ppmv}$ & 1.651 & 1.640 & 1.662 & 1.657 & 1.640 & 1.648 & 1.654 & 1.661 & 1.633 & 1.658 & 1.625 & 1.646 \\
\hline NMHC, ppbv & & & & & & & & & & & & \\
\hline $\mathrm{C} 2 \mathrm{H} 2$ & 0.117 & 0.023 & 0.084 & 0.090 & 0.168 & 0.227 & 0.115 & 0.054 & 0.056 & 0.139 & 0.125 & 0.092 \\
\hline & & & & & All & kanes & & & & & & \\
\hline $\mathrm{C} 2 \mathrm{H} 6$ & 0.625 & 0.491 & 0.498 & 0.423 & 1.128 & 1.465 & 1.088 & 1.155 & 0.753 & 0.854 & 1.294 & 0.814 \\
\hline C3H8 & 0.448 & 0.242 & 0.238 & 0.195 & 1.228 & 1.333 & 0.972 & 0.869 & 0.496 & 0.878 & 1.096 & 0.714 \\
\hline iso-C4H10 & 0.040 & 0.017 & 0.028 & 0.036 & 0.069 & 0.062 & 0.054 & 0.164 & 0.055 & 0.045 & 0.049 & 0.061 \\
\hline $\mathrm{n}-\mathrm{C} 4 \mathrm{H} 10$ & 0.197 & 0.128 & 0.129 & 0.091 & 0.422 & 0.447 & 0.325 & 0.476 & 0.205 & 0.238 & 0.389 & 0.281 \\
\hline iso-C5H12 & 0.040 & 0.017 & 1.560 & 0.290 & 0.093 & 0.116 & 0.222 & 1.852 & 0.056 & 0.043 & 0.131 & 0.036 \\
\hline $\mathrm{n}-\mathrm{C} 5 \mathrm{H} 12$ & 0.401 & 0.099 & 0.132 & 0.102 & 0.727 & 0.753 & 0.641 & 0.517 & 0.154 & 0.408 & 0.617 & 0.701 \\
\hline néopentane & nd & nd & 0.035 & 0.004 & 0.008 & 0.009 & 0.006 & 0.013 & 0.011 & 0.005 & 0.009 & nd \\
\hline 2methyl-pentane & nd & 0.023 & 0.067 & 0.022 & 0.031 & 0.046 & 0.059 & 0.259 & 0.053 & 0.011 & 0.030 & 0.011 \\
\hline 3methyl-pentane & 0.012 & 0.012 & 0.033 & 0.013 & nd & 0.022 & 0.040 & 0.238 & 0.016 & nd & $<0.01$ & nd \\
\hline $\mathrm{n}-\mathrm{C} 6 \mathrm{H} 14$ & 0.056 & 0.078 & 0.123 & 0.062 & 0.185 & 0.181 & 0.173 & 0.672 & 0.086 & 0.096 & 0.147 & 0.093 \\
\hline & & & & & Alt & enes & & & & & & \\
\hline $\mathrm{C} 2 \mathrm{H} 4$ & 1.225 & 0.865 & 0.171 & 0.244 & 2.030 & 3.852 & 2.306 & 1.973 & 4.833 & 1.651 & 1.893 & 1.504 \\
\hline $\mathrm{C} 3 \mathrm{H} 6$ & 1.465 & 0.732 & 0.936 & 0.056 & 2.424 & 2.978 & 2.249 & 1.718 & 3.573 & 2.220 & 2.035 & 1.993 \\
\hline trans-2-C4H8 & 0.047 & 0.033 & 0.023 & 0.017 & 0.037 & 0.045 & 0.036 & 0.058 & 0.138 & 0.032 & 0.031 & 0.056 \\
\hline 1-C4H8 & 0.390 & 0.237 & 0.221 & 0.182 & 0.480 & 0.640 & 0.506 & 0.710 & 0.736 & 0.357 & 0.477 & 0.412 \\
\hline iso-C4H8 & 0.376 & 0.415 & 0.390 & 0.280 & 0.453 & 0.561 & 0.559 & 0.778 & 0.785 & 0.401 & 0.371 & 0.412 \\
\hline cis-2-C4H8 & 0.046 & 0.028 & 0.025 & 0.016 & 0.034 & 0.040 & 0.036 & 0.054 & 0.116 & 0.027 & 0.028 & 0.054 \\
\hline $1-\mathrm{C} 5 \mathrm{H} 10$ & 0.701 & 0.152 & 0.235 & 0.202 & 0.973 & 1.236 & 1.079 & 0.686 & 0.366 & 0.584 & 0.855 & 0.970 \\
\hline 1-C6H12 & 0.089 & 0.099 & 0.070 & 0.082 & 0.122 & 0.150 & 0.106 & 0.935 & 0.161 & 0.085 & 0.107 & 0.100 \\
\hline & & & & & & ienes & & & & & & \\
\hline propadiene & 0.005 & nd & nd & nd & 0.012 & 0.009 & 0.007 & nd & nd & 0.006 & 0.007 & 0.003 \\
\hline 1.2butadiène & 0.048 & nd & nd & 0.006 & 0.054 & 0.061 & 0.028 & 0.007 & 0.012 & 0.039 & 0.042 & 0.011 \\
\hline 1.3butadiène & 0.022 & 0.014 & 0.030 & 0.013 & 0.019 & 0.025 & 0.014 & 0.020 & 0.021 & 0.014 & 0.017 & 0.010 \\
\hline
\end{tabular}

\section{Supersaturation of the Surface Sea Water In NMHC}

In seawater, ethene and propene are the most abundant species with mixing ratios of 2.7 to 58 and 6 to 75 ppbv, respectively. Mixing ratios of 1 and iso-butene $\left(\mathrm{C}_{4} \mathrm{H}_{8}\right)$, ethane $\left(\mathrm{C}_{2} \mathrm{H}_{6}\right)$, and propane $\left(\mathrm{C}_{3} \mathrm{H}_{8}\right)$ are about two times lower than for ethene. The concentrations in the lagoon of the atoll are similar except for ethene which presents a significant higher contribution of $230 \mathrm{ppb}$ against 2 to $10 \mathrm{ppb}$ for the other main species.

Seawater samples collected on June 7 and 11 present NMHC concentrations of about 1 order of magnitude greater than the concentrations of the first sample collected on June 4. The origin of this variability of the dissolved NMHC concentrations is not known, however, the study of the NMHC vertical distribution in the seawater by Swinnerton and Linnenbom [1967] and more recently by Bonsang and Lambert [1990] revealed the presence of maxima in the euphotic zone. It is therefore reasonable to assume that the NMHC present at the sea surface can be produced at least partly in depth. Thus the increase of sea surface NMHC water concentrations could be attributed to a mixing of the superficial water, under the influence of a greater ventilation as occurring during the second period of the experiment.

Despite this great variability it appears that the concentrations of the different NMHC covary, according to our previous observations in the tropical Indian and North Pacific oceans [Bonsang et al., 1988, 1989]. The ratios of the NMHC concentrations to that of ethene used as a reference are constant in the open ocean within a factor of 2 (3 for $\mathrm{C}_{2} \mathrm{H}_{2}$ and $\mathrm{n}_{6} \mathrm{H}_{14}$; Table 1).

Taking into account our atmospheric measurements (Table 
TABLE 2. (continued)

\begin{tabular}{|c|c|c|c|c|c|c|c|c|c|c|c|c|c|}
\hline \multicolumn{14}{|c|}{ Flight Number } \\
\hline & 4 & 4 & 4 & 5 & 5 & 6 & 6 & 6 & - & 7 & 7 & 7 & 7 \\
\hline Date & June 8 & June 8 & June 8 & June 10 & June 10 & June 11 & June 11 & June 11 & Junel 1 & June 11 & 1 June 11 & June 11 & Junel1 \\
\hline Local hour & 1810 & 1735 & 1620 & 1820 & 1744 & 1115 & 1000 & 1000 & 0655 & 1554 & 1613 & 1556 & 1535 \\
\hline Altitude, $\mathrm{m}$ & 300 & 600 & 850 & 0 & 500 & $\mathbf{0}$ & 375 & 1595 & $\mathbf{0}$ & 200 & 750 & 1200 & 0 \\
\hline Wind direction & 80 & & & 60 & & 330 & & & & 340 & & & \\
\hline Wind speed, $\mathrm{m} / \mathrm{s}$ & 11 & & & 11.5 & & 5 & & & & 5.5 & & & \\
\hline $\mathrm{UV}, \mathrm{mW} / \mathrm{cm}^{2}$ & 0 & 0.04 & 0.23 & 0 & 0 & 3.9 & $1.7-3.4$ & $1.7-3.4$ & 0 & 0.96 & 2.71 & 1.95 & 1.45 \\
\hline Sampling mean & S.A.M. & S.A.M. & S.A.M. & MAN & S.A.M. & MAN & B. & B. & MAN & S.A.M. & S.A.M. & S.A.M. & MAN \\
\hline $\mathrm{CH}_{4}, \mathrm{ppmv}$ & 1.673 & 1.627 & 1.657 & 1.628 & 1.632 & 1.652 & 1.622 & 1.635 & 1.619 & 1.603 & 1.630 & 1.662 & 1.645 \\
\hline \multicolumn{14}{|l|}{ NMHC, ppbv } \\
\hline $\mathrm{C} 2 \mathrm{H} 2$ & 0.145 & 0.051 & 0.062 & 0.110 & 0.119 & 0.022 & 0.082 & 0.087 & 0.052 & 0.020 & 0.025 & 0.071 & 0.049 \\
\hline \multicolumn{14}{|c|}{ Alkanes } \\
\hline $\mathrm{C} 2 \mathrm{H} 6$ & 1.202 & 0.454 & 0.630 & 0.980 & 1.258 & 0.360 & 0.560 & 1.834 & 0.414 & 0.435 & 0.407 & 0.620 & 0.635 \\
\hline $\mathrm{C} 3 \mathrm{H} 8$ & 0.561 & 0.177 & 0.321 & 0.841 & 0.720 & 0.102 & 0.210 & 0.770 & 0.127 & 0.103 & 0.115 & 0.231 & 0.426 \\
\hline iso-C4H10 & 0.042 & 0.028 & 0.044 & 0.086 & 0.100 & 0.011 & 0.030 & 0.060 & 0.010 & 0.041 & 0.011 & 0.033 & 0.035 \\
\hline n-C4H10 & 0.357 & 0.071 & 0.143 & 0.300 & 0.297 & 0.051 & 0.121 & 0.295 & 0.056 & 0.159 & 0.033 & 0.113 & 0.131 \\
\hline iso-C $\mathrm{CH} 12$ & 0.049 & 0.020 & 0.126 & 0.044 & n.m. & 0.010 & 0.062 & 0.182 & 0.013 & 0.040 & 0.007 & 0.069 & 0.063 \\
\hline n-C5H12 & 0.293 & 0.064 & 0.112 & 0.637 & 0.317 & 0.065 & 0.161 & 0.248 & 0.082 & 0.047 & 0.023 & 0.299 & 0.564 \\
\hline néopentane & 0.006 & nd & 0.003 & 0.002 & 0.066 & nd & nd & nd & nd & nd & nd & nd & nd \\
\hline 2methyl-pentane & 0.032 & 0.010 & 0.050 & 0.015 & 0.509 & nd & 0.203 & 0.195 & nd & 0.032 & nd & 0.654 & 1.483 \\
\hline 3methyl-pentane & nd & 0.005 & 0.038 & nd & 0.296 & nd & 0.093 & 0.122 & nd & 0.022 & nd & 0.290 & 0.643 \\
\hline n-C6H14 & 0.233 & 0.043 & 0.125 & 0.096 & 0.290 & 0.026 & 0.145 & 0.196 & 0.034 & 0.036 & 0.012 & 0.386 & 0.773 \\
\hline \multicolumn{14}{|c|}{ Alkenes } \\
\hline $\mathrm{C} 2 \mathrm{H} 4$ & 0.532 & 2.046 & 1.134 & 2.395 & 3.944 & 0.225 & 0.231 & 0.534 & 0.172 & 0.308 & 0.157 & 1.661 & 0.151 \\
\hline C3H6 & 1.498 & 0.638 & 0.820 & 1.779 & 4.522 & 0.404 & 0.582 & 1.078 & 0.584 & 0.606 & 0.242 & 0.756 & 0.286 \\
\hline trans-2-C4H8 & 0.034 & 0.029 & 0.040 & 0.051 & 0.164 & 0.019 & 0.022 & 0.052 & 0.015 & 0.020 & 0.012 & 0.024 & 0.011 \\
\hline 1-C4H8 & 0.491 & 0.193 & 0.257 & 0.379 & 0.975 & 0.090 & 0.198 & 0.377 & 0.181 & 0.137 & 0.069 & 0.259 & 0.119 \\
\hline iso-C4H8 & 0.382 & 0.216 & 0.467 & 0.419 & 1.170 & 0.170 & 0.310 & 0.494 & 0.220 & 0.433 & 0.037 & 0.381 & 0.197 \\
\hline cis-2-C4H8 & 0.032 & 0.028 & 0.039 & 0.049 & 0.140 & 0.017 & 0.021 & 0.062 & 0.015 & 0.016 & 0.009 & 0.023 & 0.010 \\
\hline 1-C5H10 & 0.254 & 0.139 & 0.160 & 0.702 & 0.501 & 0.090 & 0.141 & 0.193 & 0.167 & 0.093 & 0.039 & 0.228 & 0.103 \\
\hline 1-C6H12 & 0.152 & 0.082 & 0.101 & 0.095 & 0.208 & 0.020 & 0.058 & 0.082 & 0.067 & 0.037 & 0.020 & 0.112 & 0.049 \\
\hline \multicolumn{14}{|c|}{ Dienes } \\
\hline propadiène & 0.008 & nd & 0.003 & 0.003 & 0.005 & nd & 0.009 & 0.010 & nd & nd & nd & 0.003 & nd \\
\hline 1.2butadiene & 0.021 & 0.006 & 0.007 & 0.016 & nd & nd & 0.011 & 0.017 & 0.007 & nd & nd & 0.006 & 0.006 \\
\hline 1.3butadiène & 0.021 & 0.006 & 0.010 & 0.011 & 0.034 & 0.004 & 0.033 & 0.063 & 0.020 & 0.008 & 0.003 & 0.029 & 0.010 \\
\hline
\end{tabular}

MAN: manual sampling at sea level; T.B.: tethered balloon sampling; B: meteorological balloon sampling; S.A.M.: "Sonde Aérologique Motorisée" or remote piloted aircraft sampling. Here nd, non detected $(<0.005 \mathrm{ppbv})$

2) and the Henry's constants, as deduced from the solubility data of McAuliffe [1966], it appears that the seawater is supersaturated with respect to the atmosphere by at least two orders of magnitude and acts as a net source of NMHC. This large supersaturation was previously reported for different oceanic areas [Bonsang et al.,1988].

Because of this large supersaturation the NMHC production by surface seawater is the piston velocity times the seawater concentration. This production is therefore independent on the Henry's constants. According to Deacon [1977] and Liss and Merlivat [1986], the piston velocity is a function of the square root of the Schmidt number of the species. It was shown by Kanakidou [1988] that for the
NMHC measured here, the variations of the piston velocity do not exceed $20 \%$. Consequently, as a first approximation, the relative magnitude of the marine emissions of the different NMHC reflects their seawater composition.

\section{NMHC Atmospheric Compositions}

The main species present in the lower atmosphere are mainly ethene, propene, ethane, and propane. Whereas the $\mathrm{CH}_{4}$ concentration is extremely constant $( \pm 1.2 \%)$, the NMHC concentrations at surface level vary over 1 order of magnitude from 0.2 to $4.8 \mathrm{ppbv}$ for ethene, 0.1 to $3.5 \mathrm{ppbv}$ for propene, 0.4 to $1.5 \mathrm{ppbv}$ for ethane, 0.1 to $1.3 \mathrm{ppbv}$ for 
propane. Other alkanes and alkenes are of the sub parts per billion level.

The average air composition at sea level, using ethene as reference is reported on Figure 2 versus that of seawater. The similarity of these compositions has been already reported by Bonsang et al. [1988, 1990] in the Indian Ocean and particularly at Amsterdam Island. It has been shown that all the NMHC there originate from seawater, except $\mathrm{C}_{2} \mathrm{H}_{6}$ whose lifetime is about 2 months, and which can partly result from continental advections. It can be similarly assumed that, except may be for $\mathrm{C}_{2} \mathrm{H}_{6}$, the NMHC measured in the lower layers over the atoll of Hao originate from the ocean surface, including $\mathrm{C}_{2} \mathrm{H}_{2}$, as previously discussed by Kanakidou et al. [1988]. This point is confirmed by the analysis of the 9 day back trajectories ending at $925 \mathrm{hPa}$ (Figure 3).

Similar comparison can be done for the samples taken at altitudes above $500 \mathrm{~m}$ (Figure 2). However, in this case it can be seen a slight difference between the seawater
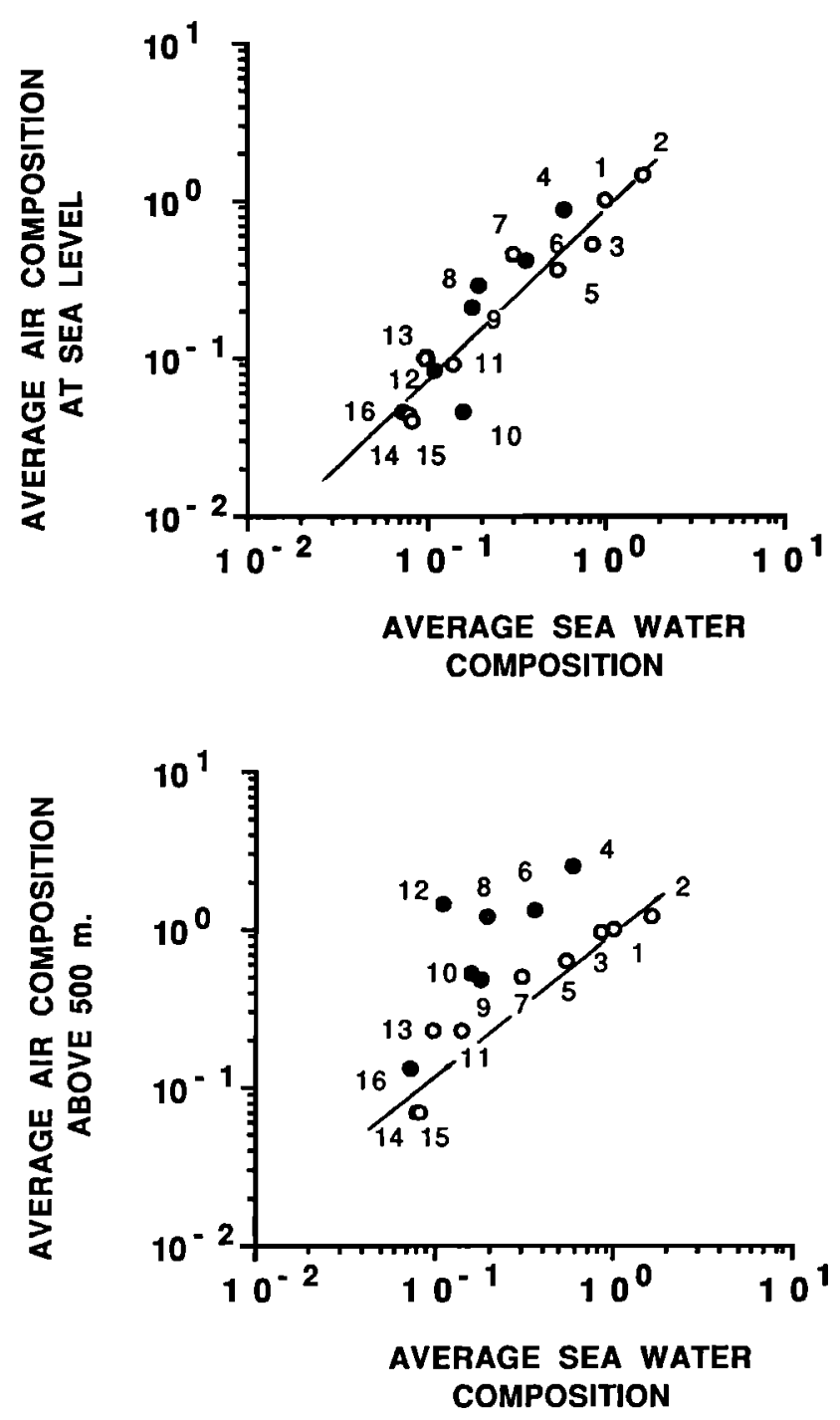

Fig. 2. Average air composition at sea level and $500 \mathrm{~m}$ versus the average seawater composition. Ethene is used as the reference (see text). Dark circles: alkanes; open circles: alkenes. 1: $\mathrm{C}_{2} \mathrm{H}_{6} ; 2: \mathrm{C}_{3} \mathrm{H}_{6} ; 3$ : iso $\mathrm{C}_{4} \mathrm{H}_{8} ; 4: \mathrm{C}_{2} \mathrm{H}_{6}$; 5: $1 \mathrm{C}_{4} \mathrm{H}_{8}$; 6: $\mathrm{C}_{3} \mathrm{H}_{8}$; 7: $1 \mathrm{C}_{5} \mathrm{H}_{10} ; 8: \mathrm{C}_{5} \mathrm{H}_{12}$; 9: $\mathrm{n} \mathrm{C}_{4} \mathrm{H}_{10}$; 10: iso $\mathrm{C}_{5} \mathrm{H}_{12}$; 11: $\mathrm{C}_{2} \mathrm{H}_{2} ; 12: \mathrm{n} \mathrm{C}_{6} \mathrm{H}_{14} ; 13: 1 \mathrm{C}_{6} \mathrm{H}_{12}$; 14: cis- $2 \mathrm{C}_{4} \mathrm{H}_{8} ; 15$ : trans-2- $\mathrm{C}_{4} \mathrm{H}_{8} ; 16$ : iso $\mathrm{C}_{4} \mathrm{H}_{10}$.

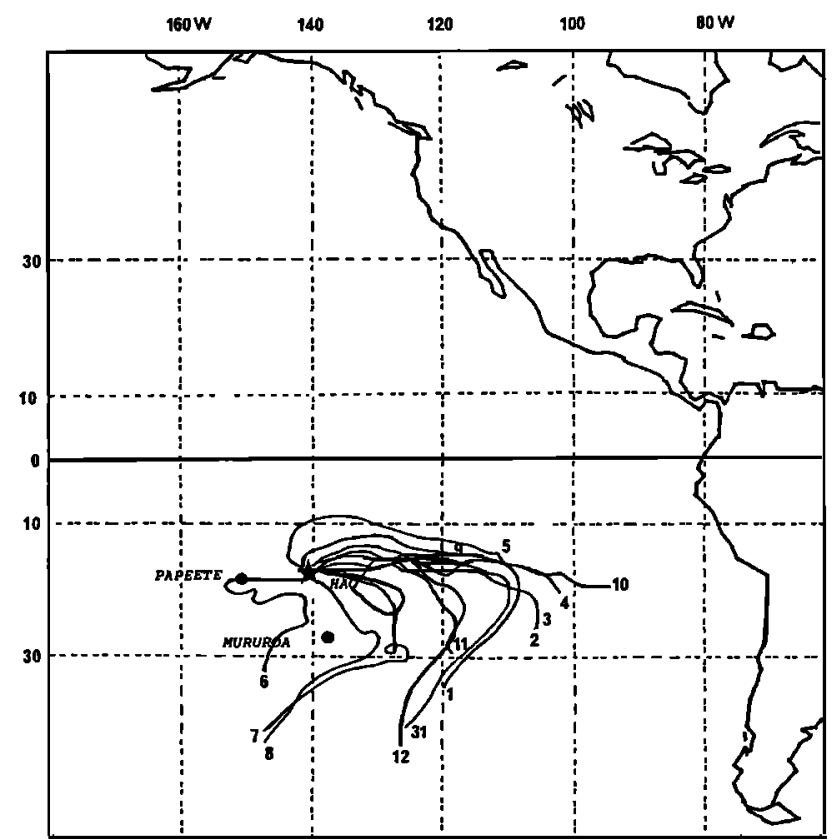

Fig. 3. Nine days back trajectories ending at $925 \mathrm{hPa}$ above the Hao atoll during the experiment. June $1,3,4,6,9,11$, and 12,1987, at 0000 UT; May 31, June 5 and 7, 1987, at $0600 \mathrm{UT}$; and June 2, 8, and 10, 1987, at $1800 \mathrm{UT}$.

composition and the atmospheric composition which presents a higher contribution of alkanes. This observation is consistent with a faster destruction of alkenes.

\section{NMHC Vertical Profiles}

During the experiment the thermal structure of the atmosphere surrounding the atoll was generally characterized by the presence of a thin absolutely unstable layer above the ocean from 100 to $300 \mathrm{~m}$. A dryer layer, generally convectively and selectively unstable, was located between 900 and $700 \mathrm{hPa}(1000$ to $3000 \mathrm{~m})$. Above this layer, up to the tropopause, a stable layer, generally absolutely stable, was observed.

The obtained vertical profiles are reported in Figures 4a to $4 \mathrm{~d}$ for the four flights $1,4,6$, and 7 undertaken during daytime.

During the flight 1 (Figure 4a) a high-pressure cell was marked by a strong temperature inversion located from 850 to $770 \mathrm{hPa}(1500$ to $3000 \mathrm{~m})$. Below this layer, convection could take place and allowed the development of small cumulus up to the inversion level. The high diffusivity coefficient between 100 and $600 \mathrm{~m}$. was due to the thermal and dynamical instability. The vertical profile of the NMHC is characterized by a strong negative concentration gradient between sea level and $100 \mathrm{~m}$ height. Above this level, alkenes are sharply decreasing versus altitude, whereas for the alkanes and acetylene, this general trend is less pronounced. However, the alkanes and alkenes vertical distributions are not directly related to their chemical reactivities. For example, ethane $\left(\mathrm{C}_{2} \mathrm{H}_{6}\right)$ and 1-butene (1$\mathrm{C}_{4} \mathrm{H}_{8}$ ) display very similar profiles despite the great difference of their kinetic constants of reaction with $\mathrm{OH}$ radicals: $0.26 \times 10^{-12} \mathrm{~cm}^{3}$ molec $^{-1} \mathrm{~s}^{-1}$ and $32 \times 10^{-12} \mathrm{~cm}^{3}$ molec $^{-1} \mathrm{~s}^{-1}$, respectively.

During the flight 4 (Figure $4 \mathrm{~b}$ ), the Hao atoll was under the influence of a large anticyclonic subtropical cell centered far at the South East at $850 \mathrm{hPa}$. At this level, the flux was north-east. At the surface a large subtropical high-pressure 

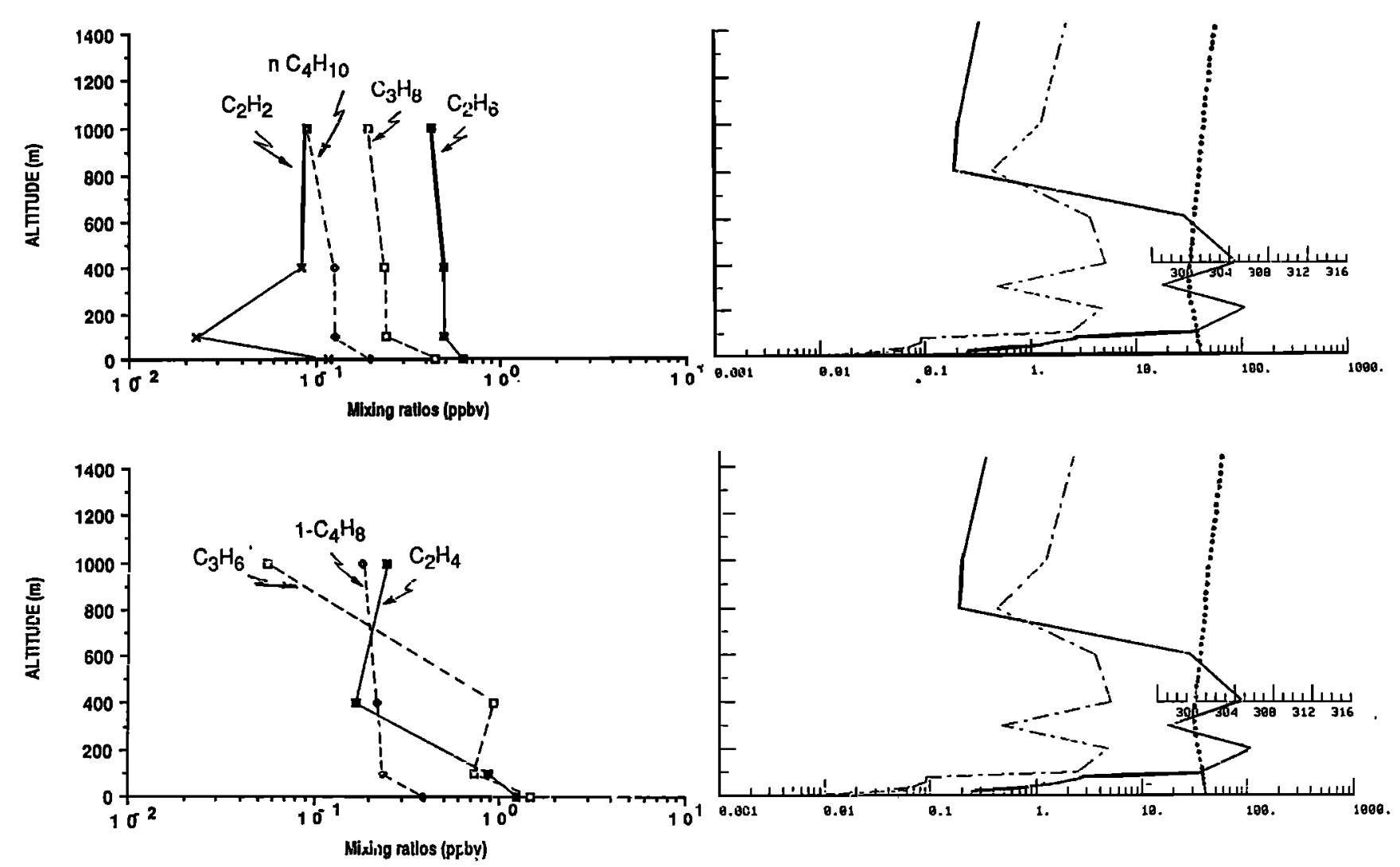

Fig. 4a. Flight 1: vertical distribution of acetylene, alkanes, mictometeorological parameters and vertical eddy diffusivity coefficient. Left panels: hydrocarbons profiles. Right panels: dotted line, potential temperatures (degrees Celsius); dashed line, horizontal wind gradient $\left(\mathrm{m} \mathrm{s}^{-1} / 100 \mathrm{~m}\right)$; full line, eddy diffusivity coefficient $\left(\mathrm{m}^{2} \mathrm{~s}^{-1}\right)$.
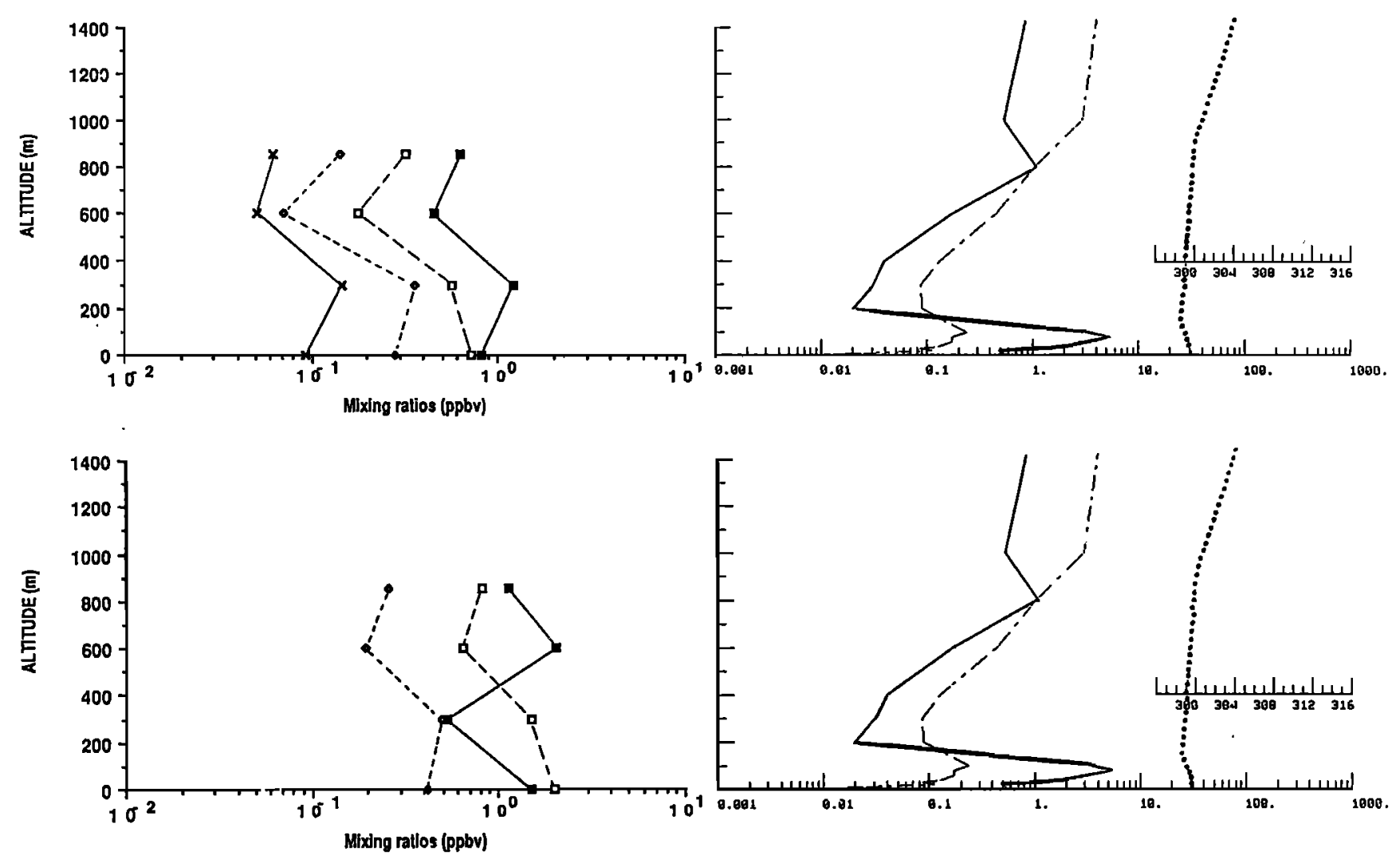

Fig. 4b. Flight 4 vertical profiles. 

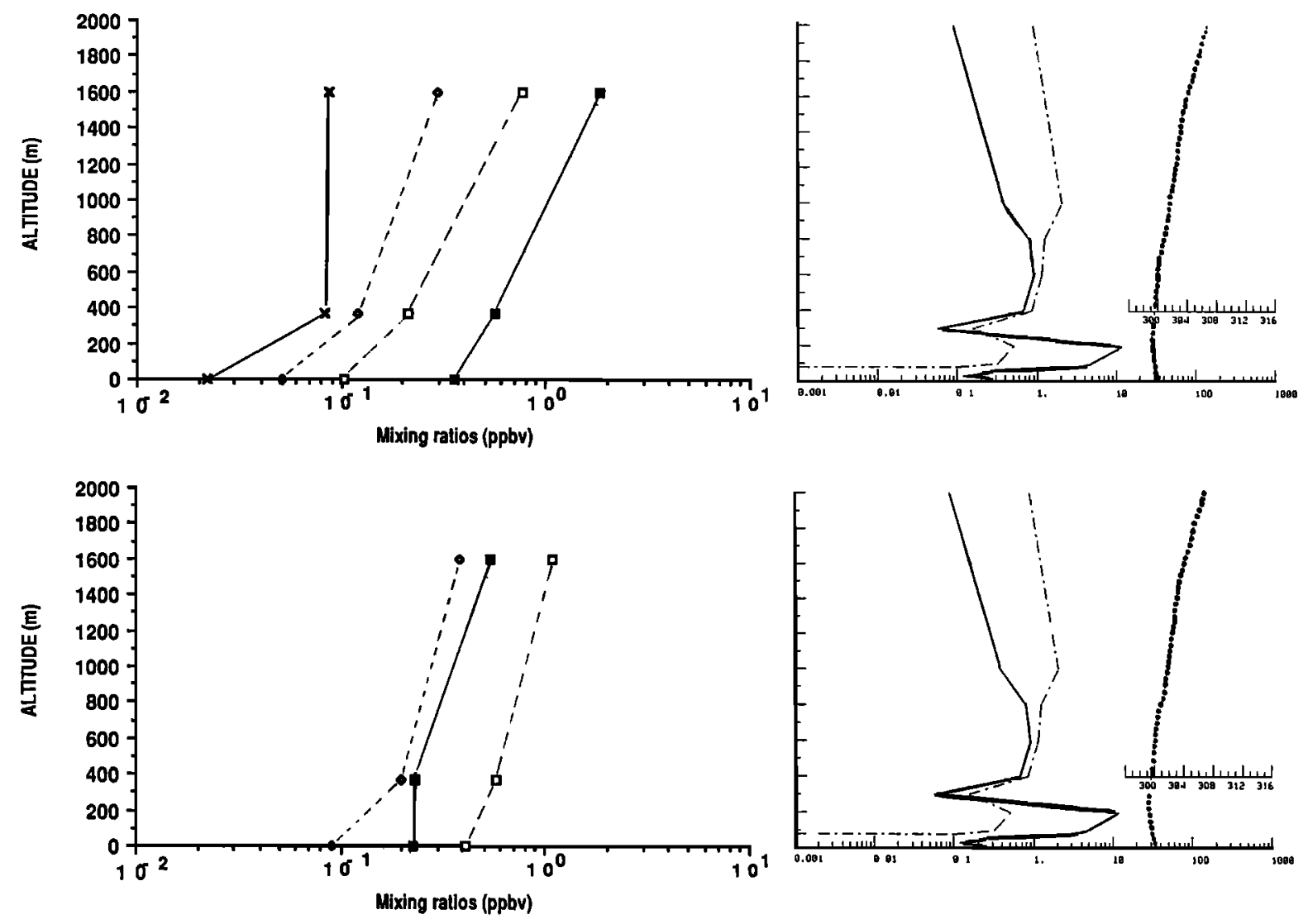

Fig. 4c. Flight 6 vertical profiles.
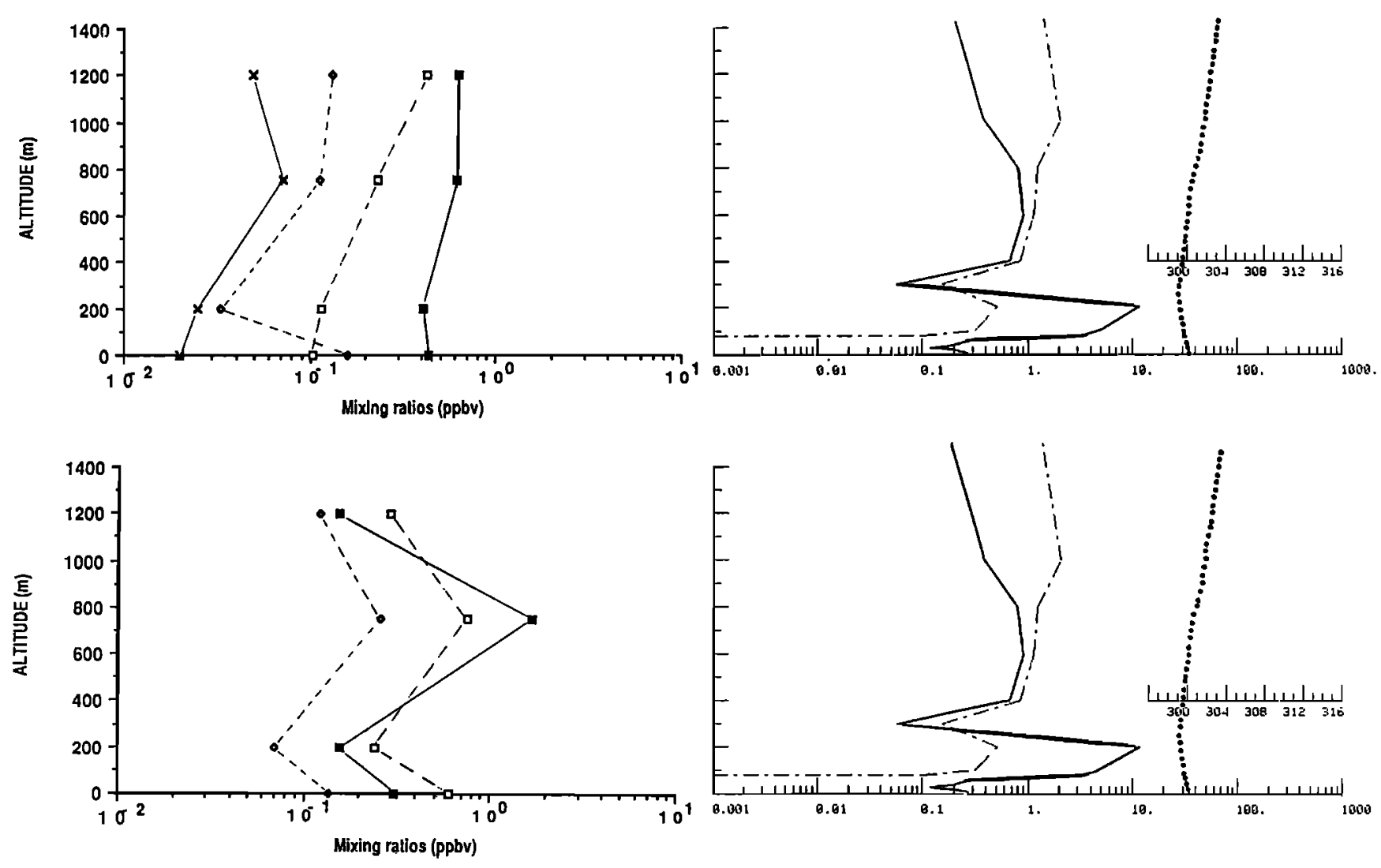

Fig. 4d. Flight 7 vertical profiles. 
cell kept up the north-east trade wind, a cold front separating the equatorial air from the tropical air remained near the atoll. This frontal system was associated with a cloudy sky. Locally, a thermal instability was observed up to $200 \mathrm{~m}$ height. Above this level the turbulence was only due to dynamical instability induced by wind gradient. Under these conditons, we can generally observe a very slight decrease of the NMHC concentrations from 0 to $600 \mathrm{~m}$ height with no systematic difference between alkanes and alkenes. All species present a relatively regular decrease up to $600 \mathrm{~m}$ and then an opposite trend from 600 to $850 \mathrm{~m}$. However, the vertical distribution of $\mathrm{C}_{2} \mathrm{H}_{4}$ appears more irregular than the others.

Both flights 6 and 7 were performed on the same day (June 11,1987$)$. The temperature profile remained constant during the day. As for the previous flights, an unstable layer was observed up to $200 \mathrm{~m}$.

For the flight 6 (Figure 4c) a very significant increasing trend versus altitude was found for all NMHC. The vertical gradient seems to be independent on the species. The analysis of the corresponding meteorological situation indicates that the sampling site was at this time in the vortex of a low pressure system.

For the flight 7 (Figure 4d), performed in the afternoon, we can note a similarity with the previous flight for the alkanes distribution. On the opposite, the alkenes distribution presents now a complex vertical structure with a maximum at $750 \mathrm{~m}$.

Nightime flights 3 and 5 do not present any systematic trend versus altitude. On the opposite, the nocturnal flight 2 shows a systematic decrease of the concentrations between 0 and $100 \mathrm{~m}$ with a concentration ratio practically constant of about 0.75 , whatever the species (Figure 5).

\section{Discussion of the Results}

It may be concluded from the seven preceding studies that, even in the center of a very large ocean, the emission and transport processes of NMHC are much too variable to lead to a reproducible typical vertical profile. This observation agrees with the conclusion of a similar study by Greenberg et al. [1990]. Such an effect is mainly due to the fact that for the considered NMHC the atmospheric dynamical processes are dominant relative to their chemical destruction.

However, it appears on the whole that anticyclonic situations are generally associated with a slight decreasing trend of the NMHC versus altitude. On the opposite, low-

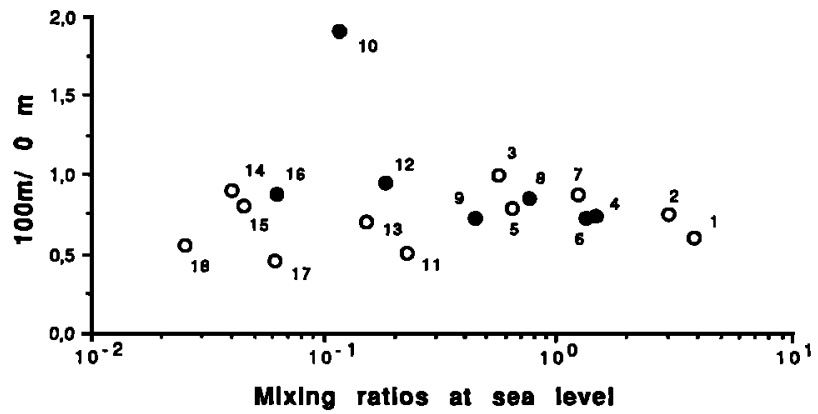

Fig. 5. Flight 2: ratios of the concentrations measured at 100 $m$ over the concentrations measured at sea level versus the sea level concentrations. Dark circules: alkanes; open circles: alkenes and dienes. 1: $\mathrm{C}_{2} \mathrm{H}_{6} ; 2: \mathrm{C}_{3} \mathrm{H}_{6} ; 3$ : iso $\mathrm{C}_{4} \mathrm{H}_{8}$; 4: $\mathrm{C}_{2} \mathrm{H}_{6} ;$ 5: $1 \mathrm{C}_{4} \mathrm{H}_{8} ; 6: \mathrm{C}_{3} \mathrm{H}_{8} ; 7: 1 \mathrm{C}_{5} \mathrm{H}_{10} ; 8: \mathrm{C}_{5} \mathrm{H}_{12}$; 9: $\mathrm{n} \mathrm{C}_{4} \mathrm{H}_{10} ; 10$ : iso $\mathrm{C}_{5} \mathrm{H}_{12} ; 11: \mathrm{C}_{2} \mathrm{H}_{2} ; 12: \mathrm{n} \mathrm{C}_{6} \mathrm{H}_{14}$; 13: $1 \mathrm{C}_{6} \mathrm{H}_{12} ; 14$ : cis-2 $\mathrm{C}_{4} \mathrm{H}_{8}$; 15: trans-2- $\mathrm{C}_{4} \mathrm{H}_{8}$; 16: iso $\mathrm{C}_{4} \mathrm{H}_{10} ; 17: 1,2$ Butadiène ; 18: 1,3 Butadiène. pressure systems result in the formation of enriched layers aloft, even for the most reactive species such as butenes or pentenes. For a given flight the profiles of alkanes and acetylene are similar, whereas some alkenes can significantly differ. As no systematic difference can be related to the chemical reactivity of the alkenes, it is clear that the emissions and transports are very variable in space and time. These subgrid processes are not well quantified by meteorological synoptic models in which they are only parametrized. However, some peculiar profiles were obtained in which the vertical gradients appear to be slightly different for different NMHC. They can be tentatively analyzed in term of chemical evolution.

In effect, the meteorological parameters measured during the experiment have shown that, between sharp inhomogeneities, the atmospheric layers actually displayed a strong stratification during vertical and horizontal transport. It may be assumed that inside a well-characterized layer, the concentration gradient of NMHC should result from both vertical transport (upward and downward) by eddy diffusion and simultaneous chemical decay, essentially due to the NMHC reaction with $\mathrm{OH}$ radicals. The vertical distribution of the NMHC within an atmospheric layer should reflect the average $\mathrm{OH}$ mixing ratios existing in this layer. Assuming a steady state, a continuity equation can be written for the concentrations of each species between two levels where the eddy diffusivity coefficient $\mathrm{K}_{\mathrm{z}}$ has a low variability: see. appendix. With this hypothesis we have

$$
\frac{\operatorname{Ln}\left(\mathrm{C}_{\mathrm{b}} / \mathrm{C}_{\mathrm{a}}\right)}{\left(\mathrm{z}_{\mathrm{a}}-\mathrm{z}_{\mathrm{b})} \cdot \sqrt{\left(\mathrm{k}_{\mathrm{OH}}\right.}\right.}=\sqrt{\left.[\mathrm{OH}]) /<\mathrm{K}_{\mathrm{z}}\right\rangle}
$$

where $C_{a}$ and $C_{b}$ are the mixing ratio of an NMHC at the levels $z_{a}$ and $z_{b}, k_{O H}$ its kinetic constant of oxidation by $\mathrm{OH}$ radicals, and $\left\langle\mathrm{K}_{\mathrm{Z}}>\right.$ the average value of the vertical eddy diffusivity coefficient between $z_{a}$ and $z_{b}$. The $O H$ concentration and $K_{2}$ being the same for all NMHC, the first term of this equation must be found constant.

Only five couples of samples were obtained under such conditions. Some situations with negative vertical concentration gradients, corresponding to a source located at the lower level, are observed for flight 1 between 0 and 100 $\mathrm{m}$, and flight 7 between 0 and $200 \mathrm{~m}$ and between 750 and $1200 \mathrm{~m}$. During flight 4 there was no systematic trend versus altitude. This observation can be accounted for by the previously described structure of the atmosphere surrounding the Hao atoll. However, an enriched layer was observed at $600 \mathrm{~m}$ height. Consequently, assuming that diffusion occured from both sides of this layer, the continuity equation can be applied for the two couples of samples respectively collected at 300 and $600 \mathrm{~m}$, and 600 and $850 \mathrm{~m}$.

In Figure 6 are plotted the numerical values of $\mathrm{OH} / \mathrm{K}_{2}$ versus the kinetic constant of oxidation by $\mathrm{OH}$ radicals for the five considered cases. It can be seen that, except for the flight $4(300-600 \mathrm{~m})$, the steady state hypothesis is a reasonable assumption for those alkenes with a kinetic constant greater than $20 \times 10^{-12} \mathrm{~cm}^{3}$ molec $^{-1} \mathrm{~s}^{-1}$ i.e., species whose lifetimes are short enough to allow an equilibrium between vertical transport and chemical decay. On the opposite, long-lived species, and all the considered NMHC for flight 4 (from 300 to $600 \mathrm{~m}$ ), were unable to reach such a steady state. For these cases, the decrease of $\mathrm{OH} / \mathrm{K}_{2}$ versus the chemical reactivity is in agreement with the theoritical analysis of $\mathrm{McKeen}$ et al. [1990]. In the same way the work of these authors would lead to conclude, from $\mathrm{OH} / \mathrm{K}_{\mathrm{z}}$ constant versus $\mathrm{k}_{\mathrm{OH}}$ that we deal with puff emissions from patchy sources.

The $\mathrm{OH} / \mathrm{K}$, values and the $\mathrm{OH}$ radical concentrations deduced from these gradients are reported in Table 3. The calculation of $\mathrm{K}$, was performed from the temperature and 
TABLE 3. Determination of OH Radicals Concentrations from the Vertical Gradients of NMHC

\begin{tabular}{|c|c|c|c|c|}
\hline & \multicolumn{4}{|c|}{ Flight Number } \\
\hline & $\overline{1}$ & 4 & 7 & 7 \\
\hline Date & May 31 & June 8 & June 11 & June 11 \\
\hline $\begin{array}{l}\text { Local Hour } \\
\text { Altitude, m }\end{array}$ & $\begin{array}{l}1200-1450 \\
0-100\end{array}$ & $\begin{array}{l}1620-1735 \\
600-850\end{array}$ & $\begin{array}{l}1535-1554 \\
0-200\end{array}$ & $\begin{array}{l}1556-1613 \\
750-1200\end{array}$ \\
\hline $\mathrm{UV}, \mathrm{mW} / \mathrm{cm}^{2}$ & 3.6 to 4.2 & $0.04-0.23$ & $1.0-2.7$ & $1.45-1.95$ \\
\hline $\begin{array}{l}\text { Average }[\mathrm{OH}] / \mathrm{K}_{\mathrm{z}} \\
\text { molec } \mathrm{cm}^{-5} \mathrm{~s}\end{array}$ & 213 & 5.00 & 74.1 & 8.8 \\
\hline $\begin{array}{l}\text { Average } \mathrm{Kz}, \\
\mathrm{cm}^{2} \mathrm{~s}^{-1}\end{array}$ & $7.65 \times 10^{4}$ & $8.6 \times 10^{3}$ & $4.95 \times 10^{4}$ & $1.22 \times 10^{4}$ \\
\hline $\begin{array}{l}\text { Average [OH], } \\
\mathrm{rad} \mathrm{cm}-3\end{array}$ & $1.6 \times 10^{7}$ & $4.3 \times 10^{4}$ & $3.7 \times 10^{6}$ & $1.1 \times 10^{5}$ \\
\hline
\end{tabular}

wind velocity profiles according to the parametrization defined by Louis [1979]. The calculated diffusion coefficients and the corresponding $\mathrm{OH}$ concentrations are also shown in Table 3, together with the corresponding hour of the day and the UV flux at $310 \mathrm{~nm}$. A low $\mathrm{OH}$ concentration of $4 \times 10^{4} \mathrm{rad} / \mathrm{cm}^{3}$ is observed at about 5 p.m., whereas at noontime we calculate $\mathrm{OH}$ concentrations up to $1.6 \times 10^{7} \mathrm{rad} / \mathrm{cm}^{3}$. These estimations are consistent with the expected values of $\mathrm{OH}$ radical concentrations for the latitude and season computed by Logan [1981] and Crutzen [1982], on a global scale.

\section{Conclusion}

The relative composition of the superficial seawater in this part of the Pacific ocean is well reproductible within a factor of 2, as previously pointed by Bonsang et al. [1989]. This accounts for an atmospheric relative composition at sea level similar to that of the seawater.

The atmospheric concentrations of NMHC obtained during the experiment at the Hao atoll display a very large short time variability even in this place located in the open ocean and free of any natural and anthropogenic continental
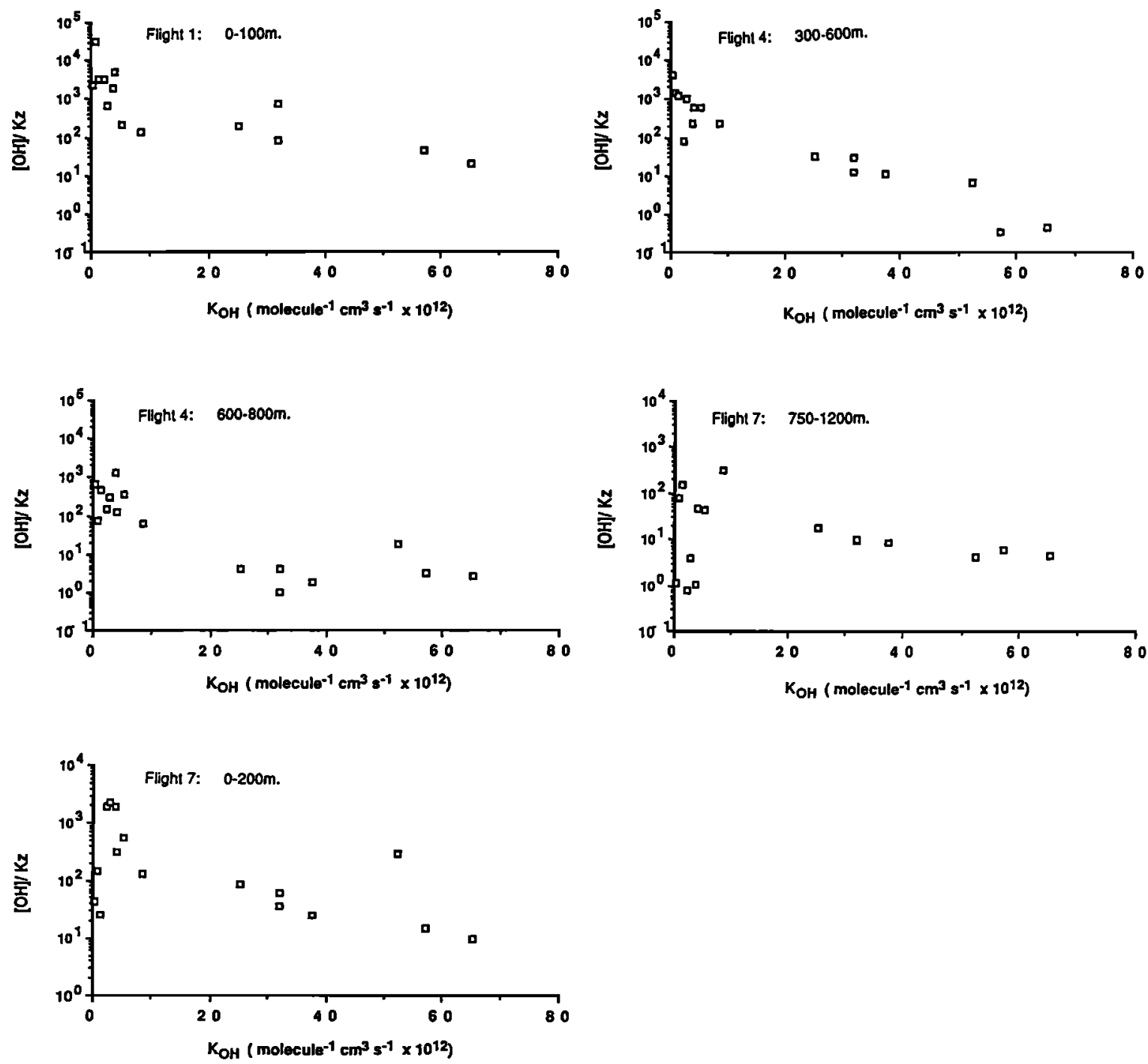

Fig. 6. $\mathrm{OH} / \mathrm{Kz}$ versus the kinetic constant of oxidation by $\mathrm{OH}$ radicals deduced from the vertical gradients of $\mathrm{NMHC}$ in the five considered cases. 
sources. This observation agrees very well with the previous results of Bonsang et al. [1989] and Singh et al. [1988], and more particularly with the measurements of Kanakidou during the cruise of the R/V Researcher, about $400 \mathrm{~km} \mathrm{NE}$ from Oahu island [Carsey et al., 1988].

For the experiment over the Hao atoll this variability could be attributed partly to the heterogeneity of concentrations in the superficial seawater, all around the atoll and partly to discontinuous marine emissions followed by a rapid transport. The irregular vertical distributions observed prevent of interpreting the results in terms of $\mathrm{OH}$ concentrations by assuming a simple continuous one-dimensional model. However, as previously pointed out, for five couples of samples, the vertical gradients were found slightly different for different NMHC. In these particular cases it was possible to assume that the proportions of short-lived species decreased from an enriched layer because of their chemical decay, mainly by $\mathrm{OH}$ radicals. Assuming that in thin atmospheric layers (typically $200 \mathrm{~m}$ thickness), vertical eddy diffusion and chemical destruction by $\mathrm{OH}$ radicals drive the atmospheric gradients of NMHC, a simple diffusion model enables us to calculate average $\mathrm{OH}$ concentrations of about $1.6 \times 10^{7} \mathrm{~cm}^{-3}$ at noon and $4 \times 10^{4} \mathrm{~cm}^{-3}$ at sunset. A test of validity of the steady state assumption is given by the constancy of the ratio $\mathrm{OH} / \mathrm{K}_{\mathrm{z}}$ versus $\mathrm{k}_{\mathrm{OH}}$ observed for the most reactive species.

\section{Appendix}

Determination of the vertical eddy diffusivity coefficient $\mathrm{K}_{\mathrm{z}}$ is based on the link of the dynamical turbulence and the thermal turbulence. Such kind of parametrization was developped by Louis [1979] for medium range forecast models developments, and great care should be taken in field experiment applications. The use of a parametrization for determining eddy flux coefficient $\mathrm{K}_{\mathrm{Z}}$ is limited to an estimation of the mean value of $\mathrm{K}_{\mathrm{z}}$ around the time during which temperature and wind profiles are performed (i.e., $0000 \mathrm{UT}$ or 1400 local time).

The Louis' technique depends on the static stability of the atmosphere so that dynamically as well as thermally forced turbulence is simulated. The temperature and wind vertical profiles are the pertinent input data whereas the roughness lenght, $z_{0}$, the assymtotic value of the mixing length $\mathrm{I}_{\mathrm{m}}$ and the surface. layer are the local input parameters. We have performed sensitvity tests in order to examine the effects of the variability of these parameters. The surface layer is arbitrary taken equal to $12 \mathrm{~m}$ and according to Justus [1985], the roughness lenght above the sea is taken equal to $0.02 \mathrm{~cm}$. These parameters are only sensitive for $K_{\text {computed in the }}$ surface layer. Above the surface layer, only the assymtotic value is sensitive. However, it is obvious that it does not influence the vertical gradient of $K_{2}$. A discussion and further recommendations can be found in the work by Tiedke et al. [1979] for the appropriate choice of $l_{\mathrm{m}}$. We have retained the value of $120 \mathrm{~m}$ considering this value as the best compromise between stable and unstable cases.

Above the surface layer the diffusion coefficient $\mathrm{K}_{\mathrm{z}}$ depends on height ( $\mathrm{z})$, stability, and wind shear according to the relationship:

$$
K_{z}=l_{m}^{2}[d v / d z] \mathcal{F}\left(R_{i}\right)
$$

where $1_{\mathrm{m}}$ is the mixing lenght as suggested by Blackadar [1962]:

$$
\mathrm{l}_{\mathrm{m}}=\mathrm{kz} /(1+\mathrm{kz} / \lambda)
$$

with $k$, the Von Karman's constant (0.4), and $\lambda$ an adjustable parameter.
$F(R i)$ is the analytical function proposed by J.F. Louis and $\mathrm{Ri}$ the Richardson number defined as

$$
\mathrm{Ri}=\mathrm{g}(\Delta \theta / \Delta \mathrm{z}) / \theta(\Delta \mathrm{v} / \Delta \mathrm{z})^{2}
$$

where $\theta$ is the potential temperature, $\Delta \theta / \Delta z$ and $\Delta v / \Delta z$ the potential temperature and the wind velocity vertical gradients respectively.

The function $F(R i)$ depends on the stability conditions: 1) in stable cases it is given by the relationship:

$$
\mathbf{F}=1 /(1+b R i)^{2}
$$

with $b=4.7$. 2) in unstable cases it is given by

$$
F=1-\left[b^{\prime} \mathrm{Ri} /\left(1+c \mathrm{Ri}^{1 / 2}\right)\right]
$$

with $b^{\prime}=9.4$, and

$$
c=7.4 l^{2} b^{\prime}\left[(z+\Delta z / z)^{1 / 3}-1\right]^{3 / 2}\left[z^{-1 / 2} \Delta z^{-3 / 2}\right]
$$

However, we have seen that $K_{2}$ became unrealistic in the stable cases, especially when $\mathrm{Ri}$ reached high values. This has been ascribed to the bad behavior of the $F$ function under such conditions. According to Kondo et al. [1978], we let Ri tend toward an assymtotic figure for high Richardson numbers. We chose $R i_{c}=2$ as the highest critical value:

$$
\mathrm{Ri}=\mathrm{Ri} /\left(1+\mathrm{Ri} / \mathrm{Ri}_{\mathrm{c}}\right)
$$

Following the above scheme to compute $K_{2}$, the Figures $4 a$ to $4 d$ show the vertical profiles of $K_{z}$ for May 31, and June 8 and 11 . Then, we have calculated arithmetic mean values between levels $\mathrm{z}_{\mathrm{a}}$ and $\mathrm{z}_{\mathrm{b}}$ :

$$
<\mathrm{K}_{\mathrm{z}}>=1 /\left(\mathrm{z}_{\mathrm{b}}-\mathrm{z}_{\mathrm{a}}\right) \sum \mathrm{K}_{\mathrm{z}}(\mathrm{z}) \Delta \mathrm{z}
$$

with $\Delta z=100 \mathrm{~m}$.

Assuming a steady state, the variation of an NMHC concentration versus altitude would be given by the continuity equation:

$$
\begin{gathered}
\partial / \partial z\left[\mathrm{~K}_{\mathrm{z}} \partial \mathrm{C}_{\mathrm{z}, \mathrm{i}} \partial \mathrm{z}\right]-\lambda_{\mathrm{i}} \mathrm{C}_{\mathrm{z}, \mathrm{i}}=0 \\
\mathrm{~K}_{\mathrm{z}} \partial^{2} \mathrm{C}_{\mathrm{z}, \mathrm{i}} \partial \mathrm{z}^{2}+\partial \mathrm{K}_{\mathrm{z}} \partial \mathrm{z} \cdot \partial \mathrm{C}_{\mathrm{z}, \mathrm{i}} / \partial \mathrm{z}-\lambda_{\mathrm{i}} \mathrm{C}_{\mathrm{z}, \mathrm{i}}=0
\end{gathered}
$$

where $\mathrm{z}$ is the altitude, $\mathrm{K}_{\mathrm{z}}$ the vertical eddy diffusivity coefficient, and $\lambda_{i}$ the kinetic constant of oxidation of the species i.

During daytime the sink due to hydroxyl radicals is dominant, and $\lambda_{i}$ is almost entirely related to the $\mathrm{OH}$ concentration and the kinetic constant $\mathrm{k}_{\mathrm{OH}, \mathrm{i}}$ of oxidation by $\mathrm{OH}$ by the formula:

$$
\lambda_{\mathrm{i}}=\mathbf{k}_{\mathrm{OH}, \mathrm{i}}[\mathrm{OH}]
$$

the equation (A2) is then integrated as follow

$$
\left.\left.\mathrm{C}_{\mathrm{b}}=\mathrm{C}_{\mathrm{a}} \exp \left[-\sqrt{\left(\mathrm{k}_{\mathrm{OH}} \cdot[\mathrm{OH}\right.}\right]\right) /\left\langle\mathrm{K}_{\mathrm{z}}\right\rangle \cdot\left(\mathrm{z}_{\mathrm{b}}-\mathrm{z}_{\mathrm{a}}\right)\right]
$$

from which we derive

$$
\frac{\operatorname{Ln}\left(\mathrm{C}_{\mathrm{b}} / \mathrm{C}_{\mathrm{a}}\right)}{\left(\mathrm{z}_{\mathrm{a}}-\mathrm{z}_{\mathrm{b})} \sqrt{\left(\mathrm{k}_{\mathrm{OH}}\right.}\right.}=\sqrt{[\mathrm{OH}]) /\left\langle\mathrm{K}_{\mathrm{z}}\right\rangle}
$$

The $\mathrm{OH}$ concentration and $\mathrm{K}_{\mathrm{z}}$ being the same for all the NMHC, the first term of (A4) must be constant. Using the kinetic constants $\mathbf{k}_{\mathrm{OH}}$ given by Atkinson [1986], the results 
are reported in Figure 6 and Table 3, and discussed in the text.

Acknowledgments. This work was supported by Centre National de la Recherche Scientifique (PIREN), Commissariat à l'Energie Atomique, Direction des Centres d'Expérimentation Nucléaire and Direction de la Météorologie Nationale (SCEM/ES). The authors thank Brigitte Schuster and Françoise Eideliman for technical assistance. This is a CFR contribution 1157 .

\section{References}

Aikin, A. C., C. C. Gallagher, C. W. Spicer, and M. H. Holdren, Measurement of methane and other light hydrocarbons in the troposphere and lower stratosphere, J. Geophys. Res., 92, 3135-3138, 1987.

Atkinson, R., Kinetics and mechanisms of the gas phase reactions of the hydroxyl radicals with organic compounds under atmospheric conditions, Chem. Rev. 8, 69$201,1986$.

Blackadar, A. K., The vertical distribution of wind and turbulent exchanges in a neutral atmosphere, J. Geophys. Res.. 67, 3095-3102, 1962.

Bonsang, B., and G. Lambert, Air-sea exchanges of non methane hydrocarbons, paper presented at The Eurotrac Symposium 1990, Garmish-Partenkirchen, April 2-5, 1990.

Bonsang, B., M. Kanakidou, and G. Lambert, Non methane hydrocarbons chemistry in the atmosphere of an equatorial forest: A case of indirect photochemical production of $\mathrm{OH}$ radicals, Geophys. Res. Lett., 14, 1250-1253, 1987.

Bonsang, B., M. Kanakidou, G. Lambert, and P. Monfray, The marine source of C2-C6 aliphatic hydrocarbons, $\underline{\mathbf{J}}$. Atmos. Chem., 6, 3-20, 1988.

Bonsang, B., M. Kanakidou, and G. Lambert, Sur la faible variabilité de composition relative des hydrocarbures légers non méthaniques dissous dans l'eau de mer superficielle, C. R. Acad. Sci., 308, série II, 495-500, 1989.

Bonsang, B., M. Kanakidou, and G. Lambert, NMHC in marine atmosphere: Preliminary results of monitoring at Amsterdam Island, J. Atmos. Chem., 11, 169-178, 1990.

Carsey, T. P., K. Bachmann, D. R. Blake, N. J. Blake, B. Bonsang, B. Dalluge, J. Greenberg, G. R. Harvey, M. Kanakidou, C. K. Laird, P. Lightman, S. Penkett, R. A. Rasmussen, S. Rowland, J. Rudolph, H. Westberg, and P. R. Zimmerman., Marine tropospheric hydrocarbons: An intercomparison exercise, Natl. Oceanic and Almos. Admin.. Boulder, Colo. Internal report, 1988.

Crutzen, P. J., The global distribution of hydroxyl, in Atmospheric Chemistry, edited by E. D. Goldberg, Springer-Verlag, New York, 1982.

Deacon, E. L., Gas transfert to an across an air-water interface, Tellus 29, 363-374, 1977.

Dickerson, R. R., G. J. Huffman, W. T. Luke, K. E. Nunnermacker, K .E. Pickering, A. C. D. Leslie, C. G. Lindsey, W. G. N. Slinn, T. J. Kelly, P. H. Daum, A. C. Delany, P. J. Greenberg, P. R. Zimmerman, J. F. Boatman, J. D. Ray, and D. H. Stedman, Thunderstorm: An important mechanism in the transport of air pollutants, Science, 235, 460-465,1987.

Ehhalt, D. H., J. Rudolph, F. Meixner, and U. Schmidt, Measurements of selected C2-C5 hydrocarbons in the background troposphere: Vertical and latitudinal variations. J. Atmos. Chem., 3, 29-52,1985.

Greenberg J. P., P. R. Zimmerman, and P. Haagenson, Tropospheric hydrocarbons and $\mathrm{CO}$ profiles over the U.S. west coast of Alaska, J. Geophys. Res., 95, 14,015$14,026,1990$
Justus, C. G., Wind Energy in Hanbook of Applied Meteorology, edited by D. Houghton, pp 915-944, John Wiley, New York, 1985.

Kanakidou, M., B. Bonsang, J. C. Le Roulley, G.Lambert, D. Martin, and G. Sennequier, Marine source of atmospheric acetylene, Nature 333, 51-52, 1988.

Kondo J., O. Kanechika, and N. Yasuda, Heat and momenum transfers under strong stability in the atmospheric surface layer, J. Atmos. Sci., 35, 1012$1021,1978$.

Lamontagne, R. A., J. W. Swinnerton, and W. J. Linnenbom, C1-C4 hydrocarbons in the north and south Pacific,Tellus, 26, 71-77, 1973.

Liss, P. S., and L. Merlivat, Air-sea exchanges rates: Introduction and synthesis, in The Role of Air-Sea Exchanges in Geochemical Cycling, NATO ASI Ser. C185, edited by Buat-Ménard, pp. 113-128, D. Reidel, Dordrecht, 1986.

Logan, J. A., M. J. Prather, S. C. Wofsy , and M. B. Mc Elroy, Tropospheric chemistry: A global perspective, J. Geophys. Res., 86, 7210-7254, 1981.

Louis, J. F., A parametric model of vertical eddy fluxes in the atmosphere, Boundary Layer Meteorol., 17, 187-202, 1979.

Martin, D., Remotely piloted aircraft for atmospheric soundings, in The Low Level Intercomparison Experiments, Boulder, Colorado, Aug.-Sept. 1979, WMO Rep. 3 , pp. 18-25, World Meteorol. Org., Geneva, 1980.

Martin, D., C. Mithieux, and B. Strauss, On the use of the synoptic vertical wind component in a transport trajectory model, Atmos. Environ. 21, 45-52, 1987.

Martin, D., G. Bergametti, and B. Strauss, On the synoptique vertical velocity in trajectory models: validation by geochemical tracers, Atmos. Environ., 24, 2059-2069, 1990.

Mc Auliffe, C., Solubility of parrafin, cycloparrafin, olefin, acetylene, cycloolefin, and aromatic hydrocarbons, J. Phys. Chem. 70, 1267-1275, 1966.

McKeen, S. A., M. Trainer, E. Y. Hsie, R. K. Tallamraju, and C. S. Liu, On the indirect determination of atmospheric $\mathrm{OH}$ radical concentrations from reactive hydrocarbon measurements, J. Geophys. Res., 95, 7493$7500,1990$.

Singh, H. B., W. Vieze and L. J. Salas, Measurements of selected $\mathrm{C}_{2}-\mathrm{C}_{5}$ hydrocarbons in the troposphere: latitudinal, vertical, and temporal variations, J. Geophys. Res. 93, 15861-15878, 1988.

Swinnerton, J. W., and W .J. Linnenbom, Gaseous hydrocarbons in sea water: Determination, Science 156, 1119-1120, 1967.

Tiedtke, M., J. F. Geleyn, A. Hollingsworth, and J.F. Louis, ECMWF model parametrization of sub-grid scale processes, Tech. Rep. 10, Eur. Cent. for Medium Range Weather Forecasts, Reading, U.K., Jan. 1989.

B. Bonsang, M. Kanakidou, G. Lambert and J.C. Le Roulley, Centre des Faibles Radioactivités, Laboratoire mixte CNRS/CEA Domaine du CNRS, 91198, Gif-sur-Yvette, France.

D. Martin, and G. Sennequier, Direction de la Météorologie Nationale, Etablissement d'Etudes et de Recherches Météorologiques, 78114, Magny-les-Hameaux, France.

\footnotetext{
(Received February 1, 1990;

revised October 31, 1990;

accepted November 20, 1990.)
} 